\title{
Pengaruh aspek kerentanan terhadap aksesibilitas sumber daya usaha ternak sapi potong
}

\author{
Amam ${ }^{1,}{ }^{*}$, Roni Yulianto ${ }^{1}$, Nur Widodo ${ }^{1}$, Sukron Romadhona ${ }^{2}$ \\ ${ }^{1}$ Department of Animal Husbandry, Faculty of Agriculture, Universitas Jember, Jember, 68121 \\ ${ }^{2}$ Department of Soil Science, Faculty of Agriculture, Universitas Jember, Jember, 68121 \\ *Correspondence: amam.faperta@unej.ac.id
}

Received: January 7th, 2020; Accepted: March 9th 2020 ; Published online: July 17th 2020

\section{Abstrak}

Tujuan: Tinggi dan rendahnya aksesibilitas peternak terhadap sumber daya dipengaruhi oleh aspek kerentanan usaha ternak, yang akhirnya akan mempengaruhi pengembangan usaha ternak. Penelitian ini bertujuan untuk mengkaji pengaruh aspek kerentanan terhadap sumber daya usaha ternak sapi potong.

Metode: Penelitian dilakukan di Bulan Juni hingga Agustus 2019 di Desa Grujugan Kidul, Kecamatan Grujugan, Kabupaten Bondowoso. Responden adalah semua peternak sapi potong di Desa Grujugan Kidul. Jumlah responden sebanyak 174 peternak (total sampling). Pengambilan data menggunakan metode Focus Group Discussion (FGD), observasi, dan survei. Survei dilakukan dengan menggunakan wawancara dan pengisian kuisioner berskala likert +1 sampai +5 . Data dianalisis menggunakan metode Partial Least Square (PLS).

Hasil: Hasil penelitian menunjukkan bahwa aspek kerentanan berpengaruh negatif secara signifikan terhadap sumber finansial, teknologi, dan fisik masing-masing sebesar -0,437; -0,215; dan $-0,346$.

Kesimpulan: Kesimpulan penelitian menunjukkan bahwa aspek kerentanan usaha ternak sapi potong dapat mempengaruhi aksesibilitas peternak terhadap sumber daya secara negatif, sehingga aspek kerentanan tersebut harus mendapat perhatian dari para pemangku kepentingan untuk pengembangan komoditas sapi potong.

Kata Kunci: Aspek kerentanan; Sumberdaya; Finansial, Teknologi; Fisik.

\section{Abstract}

Objective: High and low accessibility of farmers to resources were influenced by vulnerability aspects of livestock businesses, which will ultimately affect the development of livestock businesses. This study aims to examine the effect of vulnerability aspects cattle farm resources accessibility.

Methods: The study was conducted in June to August 2019 in Grujugan Kidul Village, Grujugan Sub-district, Bondowoso District. Respondents were all beef cattle farmers in the Grujugan Kidul Village. The number of respondents was 174 farmers (total sampling). Retrieval of data using the Focus Group Discussion (FGD), observation, and survey methods. The survey methods was conducted using interviews and filling out questionnaires on a likert scale of +1 to +5 . Data were analyzed using the Partial Least Square (PLS) method.

Results: The results showed that the aspect of vulnerability had a significant negative effect on financial, technological, and physical resources respectively $-0.437 ;-0.215$; and -0.346 . 
Conclusions: The conclusion of the study shows that the vulnerability aspect of cattle farm can negatively affect on the resources accessibility of farmers, so the vulnerability aspect must receive the attention of stakeholders for the development of beef cattle commodities.

Keywords: Vulnerability aspects; resources; financial; technological; physical

\section{PENDAHULUAN}

Aspek kerentanan usaha ternak merupakan berbagai kondisi risiko, baik berupa risiko alam maupun risiko buatan yang dapat menimbulkan risiko kerugian pada usaha ternak [1]. Aspek kerentanan merupakan bagian dari risiko bisnis di dalam usaha ternak. Beberapa aspek kerentanan di dalam usaha ternak sapi potong diantaranya ialah sulit mencari pakan saat musim kemarau, sapi sulit bunting, dan ketersediaan air tidak merata [2]. Berbagai aspek kerentanan tersebut kemudian menjadi masalah serius dalam upaya pengembangan usaha ternak [3], khususnya pengembangan sapi potong di Desa Grujugan Kidul, Kecamatan Grujugan, Kabupaten Bondowoso.

Desa Grujugan Kidul merupakan salah satu Desa Binaan Universitas Jember untuk pengembangan komoditas peternakan sapi potong yang berorientasi untuk penggemukan. Peraturan Pemerintah (PP) Nomor 6 Tahun 2017 tentang Pemberdayaan Peternak menjadi dasar terbentuknya SMP (Sekolah Masyarakat Peternakan) melalui Program PPDB (Program Pengabdian Desa Binaan) oleh Universitas Jember di Desa Grujugan Kidul, Kecamatan Grujugan, Kabupaten Bondoowoso.

Potensi usaha ternak sapi potong di Desa Grujugan Kidul didukung oleh ketersediaan lahan pekarangan untuk hijauan pakan (102,4 $\mathrm{Ha})$ dan area tegalan $(28,4 \mathrm{Ha})$. Lahan tersebut dioptimalkan sebagai media tanam hijauan pakan ternak berupa rerumputan dan leguminosa. Daya dukung potensi usaha ternak sapi potong juga didapat dari limbah pertanian berupa jerami padi, dedak, dan bekatul dari luas tanam padi 363 Ha dengan produksi 2.175 ton dan limbah pertanian lain berupa tongkol jagung dan jagung afkir dari luas tanam 18 Ha dengan produksi 76 ton.

Potensi tersebut yang kemudian didukung oleh berbagai sumber daya dapat menjaga keberlanjutan usaha ternak sapi potong [4], khususnya di Desa Grujugan Kidul. Sapi potong merupakan penyumbang daging terbesar dari kelompok ruminansia terhadap produksi daging nasional, sehingga usaha ternak sapi potong berpotensi untuk dikembangkan sebagai usaha yang menguntungkan jika dikelola dengan benar.

Tinggi dan rendahnya sumber daya yang dapat diakses peternak sapi potong di Desa Grujugan Kidul dipengaruhi oleh aspek kerentanan usaha ternak sebagai bagian dari risiko bisnis. Aspek risiko bisnis dapat menghambat pengembangan usaha ternak [5]. Hambatan tersebut muncul disebabkan oleh modal usaha, pemotongan betina produktif, munculnya penyakit, dan inbreeding [6]. Modal usaha dapat mempengaruhi pendapatan peternak dalam usaha ternak [7].

Tujuan dan keterbaruan (novelty) dari penelitian ini ialah mengkaji pengaruh aspek kerentanan terhadap aksesibilitas sumber daya usaha ternak sapi potong dengan menggunakan pendekatan Partial Least Square (PLS). Aksesibilitas merupakan keteraksesan (daya jangkau) atau derajat kemudahan yang dicapai atau dimiliki oleh peternak dalam mendukung usaha ternaknya [8-10]. Sumber daya yang dimaksud di dalam penelitian ialah sumber daya finansial, teknologi, dan fisik. Sumber daya finansial, teknologi, dan fisik merupakan bagian dari sumber daya internal usaha ternak [11]. Hipotesis dari penelitian ini ialah aspek kerentanan berpengaruh secara negatif terhadap sumber daya yang dapat diakses oleh peternak sapi potong di Desa Grujugan Kidul, Kecamatan Grujugan, Kabupaten Bondowoso.

\section{MATERI DAN METODE}

Penelitian dilakukan pada bulan Juni hingga Agustus 2019 di Desa Grujugan Kidul, Kecamatan Grujugan, Kabupaten Bondowoso. Desa Grujugan Kidul 
merupakan salah satu Desa Binaan Universitas Jember (UNEJ) di dalam pengembangan komoditas peternakan sapi potong di Kabupaten Bondowoso, sehingga lokasi penelitian ditentukan secara purposive sampling.

Data penelitian terdiri dari data primer dan data sekunder. Data primer didapatkan langsung dari responden (narasumber) yang merupakan peternak sapi potong, sedangkan data sekunder didapatkan dari Dinas Pertanian Bidang Peternakan dan Kesehatan Hewan serta Badan Pusat Statistik Kabupaten Bondowoso. Responden adalah semua peternak sapi potong sebanyak 174 orang di Desa Grujugan Kidul (total sampling). Data penelitian diperoleh dengan menggunakan metode Focus Group Discussion (FGD), observasi, dan survei. Metode survei dilakukan dengan menggunakan wawancara dan pengisian kuisioner berskala likert +1 sampai dengan +5 . Skala +1 memiliki makna sangat tidak setuju, skala +2 memiliki makna tidak setuju, skala +3 memiliki makna kurang setuju, skala +4 memiliki makna setuju, dan skala +5 memiliki makna sangat setuju.

Data dianalisis menggunakan metode Partial Least Square (PLS) dengan aplikasi SmartPLS 2.0. Salah satu keunggulan menggunakan metode PLS ialah dapat menguji atau memperkuat teori-teori yang lemah dan/atau menemukan teori yang baru. Partial Least Square (PLS) terdiri dari dua macam pengujian, yaitu outer model dan inner model. Kriteria uji pada outer model terdiri dari uji indikator (nilai outer loading), nilai Average Variance Extracted (AVE), nilai Cronbach's Alpha (CA), dan nilai Composite Reliability (CR). Kriteria uji pada inner model terdiri dari nilai koefisien determinasi $\left(R^{2}\right)$, nilai t-statistik, dan nilai koefisien parameter.

Variabel penelitian terdiri dari aspek kerentanan usaha ternak sapi potong $(X)$, sumber daya finansial $\left(\mathrm{Y}_{1}\right)$, sumber daya teknologi $\left(\mathrm{Y}_{2}\right)$, dan sumber daya fisik $\left(\mathrm{Y}_{3}\right)$. Indikator dari masing-masing variabel

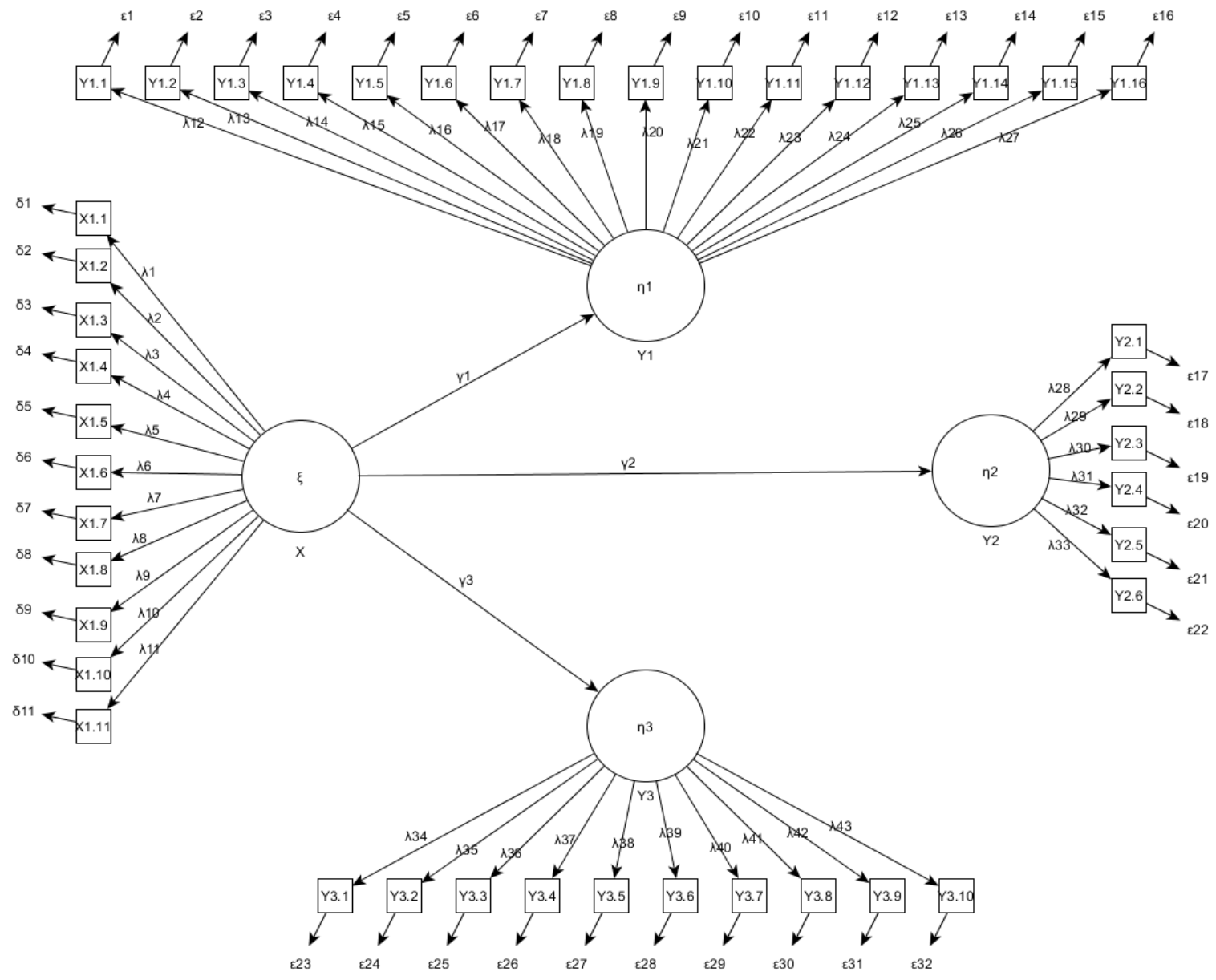

Gambar 1. Model hubungan sesama variabel 
tersebut diuraikan di dalam Tabel 1 . Berdasarkan variabel dan indikator pada Tabel 1, maka model hubungan sesama variabel dijelaskan pada Gambar 1. Bentuk persamaan matematis berdasarkan Gambar 1 dijelaskan sebagai berikut:

Variabel laten eksogen $(X) /$ reflektif

$\begin{array}{ll}X_{1.1}=\left(\lambda_{1} \xi_{1}\right)+\delta_{1} & X_{1.7}=\left(\lambda_{7} \xi_{1}\right)+\delta_{7} \\ X_{1.2}=\left(\lambda_{2} \xi_{1}\right)+\delta_{2} & X_{1.8}=\left(\lambda_{8} \xi_{1}\right)+\delta_{8} \\ X_{1.3}=\left(\lambda_{3} \xi_{1}\right)+\delta_{3} & X_{1.9}=\left(\lambda_{9} \xi_{1}\right)+\delta_{9} \\ X_{1.4}=\left(\lambda_{4} \xi_{1}\right)+\delta_{4} & X_{1.10}=\left(\lambda_{10} \xi_{1}\right)+\delta_{10}\end{array}$

$$
\begin{aligned}
& X_{1.5}=\left(\lambda_{5} \xi_{1}\right)+\delta_{5} \\
& X_{1.6}=\left(\lambda_{6} \xi_{1}\right)+\delta_{6}
\end{aligned} \quad X_{1.11}=\left(\lambda_{11} \xi_{1}\right)+\delta_{11}
$$

Variabel laten endogen $\left(\mathrm{Y}_{1}\right) /$ reflektif

\begin{tabular}{|c|c|c|}
\hline Variabel & Indikator & Notasi \\
\hline \multirow{11}{*}{$\begin{array}{l}\text { Aspek kerentanan usaha } \\
\text { ternak sapi potong }(X)\end{array}$} & sulit cari pakan saat kemarau & $\mathrm{X}_{1.1}$ \\
\hline & ketersediaan air tidak merata & $\mathrm{X}_{1.2}$ \\
\hline & harga jual sapi hidup tidak stabil & $\mathrm{X}_{1.3}$ \\
\hline & kurangnya perhatian dari pemerintah dan dinas terkait & $\mathrm{X}_{1.4}$ \\
\hline & kurang paham dengan manajemen pemeliharaan sapi yang baik & $\mathrm{X}_{1.5}$ \\
\hline & kesehatan ternak & $X_{1.6}$ \\
\hline & sapi sulit bunting & $X_{1.7}$ \\
\hline & pemanfaatan kotoran sapi & $\mathrm{X}_{1.8}$ \\
\hline & penanganan kotoran sapi & $\mathrm{X}_{1.9}$ \\
\hline & kesulitan menangani sapi saat melahirkan & $X_{1.10}$ \\
\hline & sapi sering keguguran & $\mathrm{X}_{1.11}$ \\
\hline \multirow[t]{16}{*}{ Sumber Daya Finansial ( $\left.\mathrm{Y}_{1}\right)$} & pendapatan utama & $Y_{1.1}$ \\
\hline & pendapatan dari usaha ternak sapi potong & $Y_{1.2}$ \\
\hline & pendapatan dari usaha non peternakan & $Y_{1.3}$ \\
\hline & pendapatan dari usaha ternak lain & $Y_{1.4}$ \\
\hline & pendapatan total untuk kebutuhan hidup keluarga & $Y_{1.5}$ \\
\hline & jumlah tabungan & $Y_{1.6}$ \\
\hline & jumlah hutang & $Y_{1.7}$ \\
\hline & jumlah pelunasan hutang & $Y_{1.8}$ \\
\hline & kepemilikan pedet jantan & $\mathrm{Y}_{1.9}$ \\
\hline & kepemilikan pedet betina & $Y_{1.10}$ \\
\hline & kepemilikan dara jantan & $Y_{1.11}$ \\
\hline & kepemilikan dara betina & $\mathrm{Y}_{1.12}$ \\
\hline & kepemilikan sapi jantan dewasa & $Y_{1.13}$ \\
\hline & kepemilikan sapi betina dewasa & $Y_{1.14}$ \\
\hline & kepemilikan sapi bunting & $Y_{1.15}$ \\
\hline & jumlah kepemilikan sapi & $Y_{1.16}$ \\
\hline \multirow[t]{6}{*}{ Sumber Daya Teknologi $\left(\mathrm{Y}_{2}\right)$} & pemilihan bibit & $\mathrm{Y}_{2.1}$ \\
\hline & teknologi pakan & $Y_{2.2}$ \\
\hline & kesehatan ternak & $Y_{2.3}$ \\
\hline & sistem perkandangan & $Y_{2.4}$ \\
\hline & manajemen penggemukan & $\mathrm{Y}_{2.5}$ \\
\hline & manajemen pemasaran & $Y_{2.6}$ \\
\hline \multirow[t]{10}{*}{ Sumber Daya Fisik ( $\left.\mathrm{Y}_{3}\right)$} & rumah tempat tinggal & $Y_{3.1}$ \\
\hline & kandang ternak & $Y_{3.2}$ \\
\hline & sarana transportasi & $Y_{3.3}$ \\
\hline & sarana komunikasi & $Y_{3.4}$ \\
\hline & sarana informasi & $Y_{3.5}$ \\
\hline & listrik rumah tangga & $Y_{3.6}$ \\
\hline & kepemilikan lahan & $Y_{3.7}$ \\
\hline & penggunaan lahan & $Y_{3.8}$ \\
\hline & ketersediaan air & $Y_{3.9}$ \\
\hline & ketersediaan pakan & $Y_{3.10}$ \\
\hline
\end{tabular}

$$
\begin{array}{ll}
\mathrm{Y}_{1.1}=\left(\lambda_{12} \eta_{1}\right)+\varepsilon_{1} & \mathrm{Y}_{1.9}=\left(\lambda_{20} \eta_{1}\right)+\varepsilon_{9} \\
\mathrm{Y}_{1.2}=\left(\lambda_{13} \eta_{1}\right)+\varepsilon_{2} & \mathrm{Y}_{1.10}=\left(\lambda_{21} \eta_{1}\right)+\varepsilon 10 \\
\mathrm{Y}_{1.3}=\left(\lambda_{14} \eta_{1}\right)+\varepsilon_{3} & \mathrm{Y}_{1.11}=\left(\lambda_{22} \eta_{1}\right)+\varepsilon_{11} \\
\mathrm{Y}_{1.4}=\left(\lambda_{15} \eta_{1}\right)+\varepsilon_{4} & \mathrm{Y}_{1.12}=\left(\lambda_{23} \eta_{1}\right)+\varepsilon_{12} \\
\mathrm{Y}_{1.5}=\left(\lambda_{16} \eta_{1}\right)+\varepsilon_{5} & \mathrm{Y}_{1.13}=\left(\lambda_{24} \eta_{1}\right)+\varepsilon_{13} \\
\mathrm{Y}_{1.6}=\left(\lambda_{17} \eta_{1}\right)+\varepsilon_{6} & \mathrm{Y}_{1.14}=\left(\lambda_{25} \eta_{1}\right)+\varepsilon_{14} \\
\mathrm{Y}_{1.7}=\left(\lambda_{18} \eta_{1}\right)+\varepsilon 7 & \mathrm{Y}_{1.15}=\left(\lambda_{26} \eta_{1}\right)+\varepsilon_{15} \\
\mathrm{Y}_{1.8}=\left(\lambda_{19} \eta_{1}\right)+\varepsilon 8 & \mathrm{Y}_{1.16}=\left(\lambda_{27} \eta_{1}\right)+\varepsilon 16
\end{array}
$$

Tabe1 1. Variabel dan indikator penelitian 
Variabel laten endogen $\left(\mathrm{Y}_{2}\right) /$ reflektif

$$
\begin{array}{ll}
\mathrm{Y}_{2.1}=\left(\lambda_{28} \eta_{2}\right)+\varepsilon_{17} & \mathrm{Y}_{2.4}=\left(\lambda_{31} \eta_{2}\right)+\varepsilon_{20} \\
\mathrm{Y}_{2.2}=\left(\lambda_{29} \eta_{2}\right)+\varepsilon_{18} & \mathrm{Y}_{2.5}=\left(\lambda_{32} \eta_{2}\right)+\varepsilon_{21} \\
\mathrm{Y}_{2.3}=\left(\lambda_{30} \eta_{2}\right)+\varepsilon_{19} & \mathrm{Y}_{2.6}=\left(\lambda_{33} \eta_{2}\right)+\varepsilon_{22}
\end{array}
$$

Variabel laten endogen $\left(\mathrm{Y}_{3}\right) /$ reflektif

$$
\begin{array}{ll}
Y_{3.1}=\left(\lambda_{34} \eta_{3}\right)+\varepsilon_{23} & \mathrm{Y}_{3.6}=\left(\lambda_{39} \eta_{3}\right)+\varepsilon_{28} \\
Y_{3.2}=\left(\lambda_{35} \eta_{3}\right)+\varepsilon_{24} & \mathrm{Y}_{3.7}=\left(\lambda_{40} \eta_{3}\right)+\varepsilon_{29} \\
Y_{3.3}=\left(\lambda_{36} \eta_{3}\right)+\varepsilon_{25} & \mathrm{Y}_{3.8}=\left(\lambda_{41} \eta_{3}\right)+\varepsilon_{30} \\
Y_{3.4}=\left(\lambda_{37} \eta_{3}\right)+\varepsilon_{26} & \mathrm{Y}_{3.9}=\left(\lambda_{42} \eta_{3}\right)+\varepsilon_{31} \\
Y_{3.5}=\left(\lambda_{38} \eta_{3}\right)+\varepsilon_{27} & \mathrm{Y}_{3.10}=\left(\lambda_{43} \eta_{3}\right)+\varepsilon_{32}
\end{array}
$$

Variabel laten eksogen/formatif

$$
\begin{aligned}
& Y_{1}=\left(\eta_{1} \gamma_{1}\right)+\varepsilon \\
& Y_{2}=\left(\eta_{2} \gamma_{2}\right)+\varepsilon \\
& Y_{3}=\left(\eta_{3} \gamma_{3}\right)+\varepsilon
\end{aligned}
$$

\section{HASIL DAN PEMBAHASAN}

Program Pengabdian Desa Binaan (PPDB) mempunyai lima tujuan utama, yaitu: 1) tata kelola berbasis pembentukan dan penguatan kelembagaan peternak; 2) pelayanan sosial dasar melalui pelaksanaan Program Sekolah Masyarakat Peternakan (SMP); 3) pengembangan ekonomi lokal berbasis komoditas unggulan yaitu sapi potong; 4) peningkatan kualitas lingkungan melalui konsep zero waste (pemanfaatan limbah tanaman dan limbah kotoran ternak); serta 5) pemberdayaan perempuan melalui pendampingan program diversifikasi produk olahan daging sapi.

Program PPDB dibentuk pada tahun 2019 di beberapa kabupaten di Provinsi Jawa Timur, diantaranya Kabupaten Jember,
Bondowoso, Situbondo, Lumajang, dan Probolinggo. Pelaksanaan program tersebut di Desa Grujugan Kidul, Kecamatan Grujugan, Kabupaten Bondowoso sebagai salah satu kawasan pengembangan komoditas sapi potong. Sebanyak 70\% masyarakat Desa Grujugan Kidul memiliki ternak sapi potong, meski bukan sebagai pekerjaan utama namun usaha ternak sapi potong telah dilakukan masyarakat secara turun-menurun dengan skala rumah tangga. Usaha ternak sapi potong skala rumah tangga memberikan kontribusi sebesar 6,8\% terhadap total pendapatan rumah tangga [12]. Profil peternak di Desa Grujugan Kidul diuraikan pada Tabel 2.

Usaha ternak sapi potong skala rumah tangga di Desa Grujugan Kidul pada umumnya peternak memiliki sapi sebanyak 2-4 ekor. Peternak sapi potong hanya mengandalkan dan memanfaatkan sumber daya yang tersedia. Pagi berangkat ke ladang dan siang atau sore balik ke rumah dengan membawa rumput dan limbah-limbah pertanian untuk pakan ternak. Pembelian pakan berupa konsentrat hanya sesekali dilakukan jika peternak memiliki lebihan uang setelah dikurangi biaya kebutuhan hidup rumah tangga sehari-hari. Sumber daya memiliki peranan penting untuk pengembangan usaha ternak [13], namun tinggi dan rendahnya sumber daya yang dapat diakses peternak di Desa Grujugan Kidul memungkinkan dipengaruhi oleh aspek kerentanan usaha ternak sapi potong. Pengembangan usaha berpengaruh negatif terhadap aspek risiko bisnis usaha ternak [14].

Tabel 2. Profi responden

\begin{tabular}{cccccc}
\hline Umur (tahun) & Persentase & Pendidikan & Persentase & Pengalaman (tahun) & Persentase \\
\hline $18-23$ & 1,72 & $<$ SD & 2,87 & $<2$ & 3,44 \\
$23-28$ & 5,17 & SD & 35,05 & $2-4$ & 13,79 \\
$28-33$ & 10,34 & SMP & 29,88 & $4-6$ & 20,11 \\
$33-38$ & 16,09 & SMA & 27,01 & $6-8$ & 38,50 \\
$38-43$ & 24,13 & S1 & 4,59 & $>10$ & 17,24 \\
$43-48$ & 20,11 & $>$ S1 & 0,57 & & 6,89 \\
$48-53$ & 12,64 & & & & $100 \%$ \\
$>53$ & 9,77 & $100 \%$ & $100 \%$ & & \\
\hline
\end{tabular}




\section{Uji outer model}

Kriteria uji pada outer model terdiri dari uji indikator (nilai outer loading), nilai Average Variance Extracted (AVE), nilai Cronbach's Alpha (CA), dan nilai Composite Reliability (CR). Hasil uji indikator dari masing-masing variabel (Tabel 1) ditunjukkan pada Tabel 3. Hasil pengujian nilai AVE, nilai CA, dan nilai CA ditunjukkan pada Tabel 4.

\section{Uji inner model}

Kriteria uji pada inner model terdiri dari nilai koefisien determinasi $\left(R^{2}\right)$, nilai t-statistik, dan nilai koefisien parameter. Hasil pengujian inner model ditunjukkan pada Tabel 5.

Aspek kerentanan di dalam usaha ternak merupakan suatu hal yang jarang dikaji pengaruhnya dan dampaknya terhadap usaha ternak itu sendiri. Hasil kajian ini (Tabel 5) menunjukkan bahwa aspek kerentanan memiliki dampak yang buruk (negatif) pada aksesibilitas peternak terhadap sumber daya finansial, teknologi, dan fisik. Aspek kerentanan dalam usaha ternak sapi potong harus mendapatkan perhatian khusus oleh stakeholder, sehingga tidak menghambat keberlanjutan usaha ternak dan sebagai upaya dalam mendukung pengembangan usaha ternak sapi potong di pedesaan.

Aspek kerentanan usaha ternak sapi potong (Tabel 3) meliputi sulitnya mencari pakan saat musim kemarau, ketersediaan air tidak merata, harga jual sapi hidup tidak stabil, kurangnya perhatian dari pemerintah dan dinas terkait, kurang paham dengan manajemen pemeliharaan sapi yang baik, kesehatan ternak, serta pemanfaatan dan penanganan kotoran sapi.

\section{Pengaruh aspek kerentanan usaha ternak} sapi potong terhadap sumber daya finansial

Sumber daya finansial peternak sapi potong dipengaruhi oleh aspek kerentanan sebesar 57,8\%. Aspek kerentanan usaha ternak sapi potong berpengaruh secara negatif dan signifikan (pada taraf 5\%) terhadap sumber daya finansial sebesar -0,437. Artinya bahwa, semakin rendah aspek kerentanan usaha ternak sapi potong, maka semakin tinggi sumber daya finansial yang dapat diakses peternak. Masyarakat Desa Grujugan Kidul, Kecamatan Grujugan,
Tabel 3. Hasil uji indikator

\begin{tabular}{|c|c|c|c|c|c|}
\hline Notasi & $x$ & $Y_{1}$ & $\mathrm{Y}_{2}$ & $\mathrm{Y}_{3}$ & Keterangan \\
\hline$X_{1.1}$ & 0,869 & & & & valid \\
\hline$X_{1.2}$ & 0,634 & & & & valid \\
\hline$X_{1.3}$ & 0,955 & & & & valid \\
\hline$X_{1.4}$ & 0,728 & & & & valid \\
\hline$X_{1.5}$ & 0,847 & & & & valid \\
\hline$X_{1.6}$ & 0,618 & & & & valid \\
\hline $\mathrm{X}_{1.8}$ & 0,615 & & & & valid \\
\hline$X_{1.9}$ & 0,526 & & & & valid \\
\hline$Y_{1.1}$ & & 0,645 & & & valid \\
\hline $\mathrm{Y}_{1.2}$ & & 0,828 & & & valid \\
\hline$Y_{1.5}$ & & 0,731 & & & valid \\
\hline$Y_{1.6}$ & & 0,752 & & & valid \\
\hline $\mathrm{Y}_{1.9}$ & & 0,836 & & & valid \\
\hline$Y_{1.11}$ & & 0,963 & & & valid \\
\hline $\mathrm{Y}_{1.13}$ & & 0,844 & & & valid \\
\hline $\mathrm{Y}_{1.15}$ & & 0,726 & & & valid \\
\hline $\mathrm{Y}_{1.16}$ & & 0,927 & & & valid \\
\hline $\mathrm{Y}_{2.1}$ & & & 0,811 & & valid \\
\hline$Y_{2.2}$ & & & 0,845 & & valid \\
\hline $\mathrm{Y}_{2.3}$ & & & 0,512 & & valid \\
\hline$Y_{2.5}$ & & & 0,919 & & valid \\
\hline $\mathrm{Y}_{2.6}$ & & & 0,676 & & valid \\
\hline$Y_{3.2}$ & & & & 0,515 & valid \\
\hline$Y_{3.3}$ & & & & 0,639 & valid \\
\hline$Y_{3.4}$ & & & & 0,726 & valid \\
\hline$Y_{3.5}$ & & & & 0,734 & valid \\
\hline$Y_{3.7}$ & & & & 0,651 & valid \\
\hline $\mathrm{Y}_{3.8}$ & & & & 0,712 & valid \\
\hline$Y_{3.10}$ & & & & 0,844 & valid \\
\hline
\end{tabular}

Kabupaten Bondowoso pada umumnya memilihara sapi dalam skala rumah tangga, yaitu sekitar 2-4 skala kepemilikan ternak. Salah satu aspek kerentanan ialah kebijakan pemerintah [1]. Kurangnya perhatian dari pemerintah diantaranya ialah pemerintah hanya menentukan harga jual daging sapi dan tanpa menentukan regulasi harga jual sapi hidup. Skala kepemilikan ternak yang rendah berdampak pada posisi daya tawar peternak yang lemah, sehingga penjualan ternak sangat bergantung pada makelar/belantik sapi (free raider). 
Rendahnya skala kepemilikan ternak berdampak pada mudahnya dipengaruhi oleh aspek kerentanan usaha ternak. Skala kepemilikan ternak sangat berpengaruh terhadap produktivitas ternak [14], produktivitas dan profitabilitas usaha ternak dengan skala besar lebih tinggi bila dibandingkan dengan skala kecil [15].

Aspek kerentanan yang dirasakan peternak sapi potong juga berdampak pada pendapatan peternak [16]. Semakin besar kerentanan usaha ternak maka semakin rendah keuntungan peternak. Hal tersebut dirasakan seperti kerentanan pada ketersediaan hijauan pakan saat musim kemarau, sehingga berdampak pada kesulitan peternak mencari rumput, sedangkan permasalahan utama saat musim hujan ialah rendahnya kualitas hijuan pakan dengan kadar protein kasar di bawah kebutuhan nutrisi ternak [17].

Eratnya kaitan antara aspek kerentanan usaha ternak sapi potong dengan aksesibilitas peternak terhadap sumber daya finansial menunjukkan bahwa aspek kerentanan usaha ternak harus menjadi perhatian serius oleh berbagai pihak yang mempunyai kepentingan. Kerentanan usaha ternak dapat menimbulkan risiko kerugian pada usaha ternak [1]. Sumber daya finansial usaha ternak sapi potong yang terkena dampak aspek kerentanan ialah pendapatan utama, pendapatan dari usaha ternak sapi potong, pendapatan total untuk kebutuhan hidup keluarga, jumlah tabungan, kepemilikan pedet jantan, kepemilikan dara jantan, kepemilikan sapi jantan dewasa, kepemilikan sapi bunting, dan jumlah total kepemilikan sapi.

\section{Pengaruh aspek kerentanan usaha ternak} sapi potong terhadap sumber daya teknologi

Sumber daya teknologi peternak sapi potong dipengaruhi oleh aspek kerentanan sebesar 34,7\%. Aspek kerentanan usaha ternak sapi potong berpengaruh secara negatif dan signifikan (pada taraf 5\%) terhadap sumber daya teknologi sebesar $-0,215$. Artinya bahwa, semakin rendah aspek kerentanan usaha ternak sapi potong, maka semakin tinggi sumber daya teknologi yang dapat diakses peternak. Masyarakat Desa Grujugan Kidul, Kecamatan Grujugan, Kabupaten Bondowoso pada umumnya memelihara ternak sapi potong secara intensif (dikandangkan) dengan manajemen budidaya yang sederhana (tradisional). Usaha peternakan merupakan keterpaduan antara manejemen produksi dengan manajemen keuangan, dimana manajemen produksi menentukan input dan output usaha ternak [18].

Eratnya hubungan antara aksesibilitas peternak terhadap sumber daya fisik dengan aspek kerentanan memberikan suatu temuan bahwa aspek kerentanan harus menjadi perhatian khusus pelaku usaha dan yang mempunyai kepentingan [19]. Aspek kerentanan tersebut berdampak pada pemilihan bibit ternak, teknologi pakan, kesehatan ternak, manajemen pengemukan, dan manajemen pemasaran. Pemilihan bibit menjadi sebagai yang terdampak disebabkan karena peternak di Desa Grujugan Kidul sebagian besar melakukan usaha ternak untuk penggemukan (fattening), sehingga pemilihan bibit menjadi salah satu faktor penting untuk memulai usaha penggemukan sapi potong. Permasalahan dalam pengadaan bibit sapi potong berpengaruh terhadap peningkatan produktivitas ternak [20].

Teknologi pakan dan manajemen penggemukan sebagai aspek yang terdampak oleh kerentanan usaha ternak disebabkan karena pengaruh ketersediaan pakan hijauan. Pakan (feeding) merupakan salah satu dari tiga pilar penting di dalam usaha ternak, selain pembibitan (breeding) dan manajemen

Tabel 4. Hasil uji outer model

\begin{tabular}{lcccc}
\hline Variabel & Notasi & Average Variance Extracted & Cronbach's Alpha & $\mathrm{R}_{2}$ \\
\hline Aspek kerentanan & $\mathrm{X}$ & 0,884 & 0,934 & \\
Sumber daya finansial & $\mathrm{Y}_{1}$ & 0,826 & 0,895 & 0,578 \\
Sumber daya teknologi & $\mathrm{Y}_{2}$ & 0,615 & 0,797 & 0,347 \\
Sumber daya fisik & $\mathrm{Y}_{3}$ & 0,789 & 0,852 & 0,414 \\
\hline
\end{tabular}


(management) [21]. Ketersediaan pakan hijauan saat musim kemarau sangat terbatas, sedangkan saat musim hujan melimpah, namun nilai nutrisinya lebih rendah. Protein kasar pada hijauan pakan saat musim hujan lebih rendah jika dibandingkan dengan saat musim kemarau [17].

Kesehatan ternak dan manajemen pemasaran sebagai aspek yang terdampak oleh kerentanan usaha ternak disebabkan karena harga jual ternak semakin rendah jika ternak yang dijual dalam kondisi sakit, juga risiko kematian akan semakin besar. Proses pengangkutan (transportasi) juga sangat berisiko jika ternak dalam kondisi sakit. Manajemen pemasaran yang masih tradisional menyebabkan nilai tambah yang didapatkan peternak sangat rendah. Peternak memasarkan ternaknya melalui belantik sapi (free raider), padahal variabel stock sapi (nilai sapi di akhir tahun) dapat mempengaruhi pendapatan peternak sapi potong [22].

\section{Pengaruh aspek kerentanan usaha ternak sapi potong terhadap sumber daya fisik}

Sumber daya fisik sapi potong dipengaruhi oleh aspek kerentanan sebesar 34,6\%. Aspek kerentanan usaha ternak sapi potong berpengaruh secara negatif dan signifikan (pada taraf 5\%) terhadap sumber daya fisik sebesar -0,346. Artinya bahwa, semakin rendah aspek kerentanan usaha ternak sapi potong, maka semakin tinggi sumber daya fisik yang dapat diakses peternak. Masyarakat Desa Grujugan Kidul, Kecamatan Grujugan, Kabupaten Bondowoso memelihara ternak sapi dengan tujuan untuk tabungan (saving) dan untuk usaha (business). Kepemilikan ternak terdiri dari milik pribadi dan milik orang lain yang dipelihara dengan sistem kemitraan paron kontrak (gaduhan). Hubungan kerjasama peternakan diantaranya ialah sistem bagi hasil [23], dan pola dagang umum [24].

Pengembangan usaha ternak sapi potong di pedesaan sangat dipengaruhi oleh pendapatan peternak [25]. Faktor yang mempengaruhi tinggi dan rendahnya pendapatan peternak ialah umur, tenaga kerja, kepemilikan lahan, investasi, harga beli ternak, harga jual ternak, harga pakan, dan kesehatan ternak [26]. Usaha ternak yang semakin efektif dan efisien akan menghasilkan keuntungan yang besar dan semakin kuat posisi daya saingnya [12].

Usaha ternak sapi potong sebagai usaha peternakan rakyat merupakan salah satu sumber pemenuhan permintaan daging sapi nasional [27], selain itu, sumber pemenuhan daging sapi nasional juga disumbang oleh importir sapi potong atau Asosiasi Pengusaha Feedloters Indonesia (APFINDO) dan importir daging sapi potong atau Asosiasi Pengusaha Importir Daging Sapi Indonesia (ASPIDI). Kondisi tersebut menunjukkan sudah seyogyanya aspek kerentanan usaha ternak

Tabel 5. Hasil uji inner model

\begin{tabular}{rrr}
\hline Pengujian & Nilai & Keterangan \\
\hline Koefisien determinasi $\left(\mathrm{R}^{2}\right)$ & & \\
a. Sumber daya finansial & 0,578 & \\
b. Sumber daya teknologi & 0,347 & \\
c. Sumber daya fisik & 0,414 & \\
t-statistik & & \\
a. $\quad X \rightarrow Y_{1}$ & 4,831 & signifikan \\
b. $\quad X \rightarrow Y_{2}$ & 2,205 & signifikan \\
c. $\quad X \rightarrow Y_{3}$ & 3,118 & signifikan \\
Koefisien parameter & & \\
a. $\quad X \rightarrow Y_{1}$ & $-0,437$ & pengaruh negatif \\
b. $\quad X \rightarrow Y_{2}$ & $-0,215$ & pengaruh negatif \\
c. $\quad X \rightarrow Y_{3}$ & $-0,346$ & pengaruh negatif \\
\hline
\end{tabular}

$\mathrm{t}$ tabel: 1.652 . 
sapi potong menjadi perhatian serius bagi pelaku usaha dan yang berkepentingan.

Aksesibilitas peternak terhadap sumber daya fisik yang terkena dampak oleh aspek kerentanan usaha ternak sapi potong ialah kandang ternak, sarana transportasi, sarana komunikasi, sarana informasi, kepemilikan lahan, penggunaan lahan, dan ketersediaan pakan. Berbagai sarana dan fasilitas peternak untuk usaha ternak sapi potong seperti kendang, sarana transportasi, komunikasi, dan informasi merupakan sumber daya fisik dan juga sebagai aset peternak di dalam mendukung usaha ternaknya, sehingga jika aspek kerentanan semakin besar maka sarana dan fasilitas tersebut semakin rendah tingkat kepemilikannya. Contoh aspek kerentanan terhadap ketersediaan air yang tidak merata di Desa Grujugan Kidul saat musim kemarau berdampak pada ketersediaan air yang terbatas yang digunakan untuk air minum bersih untuk ternak.

Kepemilikan lahan dan penggunaan lahan erat kaitannya dengan ketersediaan hijauan pakan sebagai sumber nutrisi untuk ternak. Aspek kerentanan terhadap terbatasanya sediaan hijauan pakan berdampak pada rendahnya produktivitas ternak sapi potong, sehingga mempengaruhi penerimaan dan keuntungan peternak. Peternak dengan keuntungan yang sedikit berdampak pada kepemilikan investasi yang terbatas, salah satunya ialah kepemilikan lahan dan penggunaan lahan untuk hijauan. Hijauan merupakan bahan pakan ternak yang diperoleh dari rerumputan dan leguminosa yang harus tersedia secara berkelanjutan baik secara kualitas maupun kuantitas [28]. Hijauan tersebut bisa didapatkan dari lahan-lahan pekarangan. Pemanfaatan lahan termasuk ke dalam sumber daya fisik usaha ternak [29], dimana sumber daya tersebut menjadi salah satu faktor di dalam pengembangan usaha ternak [30].

\section{KESIMPULAN}

Hasil penelitian menunjukkan bahwa aspek kerentanan berpengaruh negatif dan signifikan terhadap sumber daya finansial, teknologi, dan fisik masing-masing sebesar $-0,437$; -0,215; dan -0,346. Aspek kerentanan usaha ternak sapi potong di Desa Grujugan Kidul mempengaruhi akesibilitas peternak terhadap sumber daya finansial sebesar $57,8 \%$, sumber daya teknologi sebesar $34,7 \%$, dan sumber daya fisik sebesar $41,4 \%$.

\section{KONFLIK KEPENTINGAN}

Penulis menyatakan tidak ada konflik kepentingan dengan organisasi keuangan ataupun penyandang dana (sponsor) terkait isi/materi yang dibahas di dalam naskah ilmiah ini.

\section{UCAPAN TERIMA KASIH}

Penelitian ini merupakan bagian dari rangkaian penelitian yang panjang dan berkelanjutan, sehingga melibatkan banyak pihak dalam pelaksanaan penelitian ini. Tim penulis menyampaikan ucapan terimakasih kepada: a) Lembaga Penelitian dan Pengabdian kepada Masyarakat (LP2M) Universitas Jember (UNEJ); b) Kelompok Riset (KeRis) Integrated Farming System for Large Ruminant (IFSLR); c) KeRis Socio-economic Aspects of Livestock Farming and Product Technolgy; d) KeRis Agribisnis dan Agroindustri Peternakan (A2P); e) Mahasiswa Program Studi Peternakan, Fakultas Pertanian, Universitas Jember yang terlibat di dalam project research tahun anggaran 2019-2021; f) Kepala Desa Grujugan Kidul beserta perangkat desa dan masyarakat peternak sapi potong; g) Dinas Pertanian Kabupaten Bondowoso, khususnya Bidang Peternakan dan Kesehatan Hewan; serta h) Pemerintah Daerah dan Badan Perencanaan Pembangunan Daerah (BAPPEDA) Kabupaten Bondowoso.

\section{DAFTAR PUSTAKA}

1. Amam. and P. A. Harsita. 2019. Aspek kerentanan usaha ternak sapi perah di Kabupaten Malang. Agrimor. Jurnal Agribisnis Lahan Kering. 4:26-28. doi:10.32938/ag.v4i2.663.

2. Harsita, P. A. and Amam. 2019. Permasalahan utama usaha ternak sapi potong di tingkat peternak dengan pendekatan Vilfredo Pareto Analysis. 
Pros. Sem. Nas. Tek. Pet. Vet. p. 241-250. doi:10.14334/Pros.Semnas.TPV-2019-p.241 -250 .

3. Amam., M. W. Jadmiko, P. A. Harsita, R. Yulianto, N. Widodo, Soetriono, and M. S. Poerwoko. 2020. Usaha ternak sapi perah di Kelompok Usaha Bersama (KUB) Tirtasari Kresna Gemilang: Identifikasi sumber daya dan kajian aspek kerentanan. Jurnal Ilmu Peternakan dan Veteriner Tropis. doi:10.30862/jipvet.v10i1.

4. Amam, Z. Fanani, B. Hartono, and B. A. Nugroho. 2019. Broiler Livestock business based on partnership cooperation in Indonesia: The assessment of opportunities and business developments. International Journal of Entrepreneurship. 23:1-11.

5. Amam. and Soetriono. 2019. Evaluasi performa kelembagaan peternak sapi perah berdasarkan aspek risiko bisnis dan pengembangan usaha. Jurnal Ilmu dan Teknologi Peternakan Tropis. 5:8-13. doi:10.33772/jitro.v6i1.5391.

6. Otoluwa, M. A., A. H. S. Salendu, A. K. Rintjap, and M. T. Massie. 2016. Prospek pengembangan usaha ternak sapi potong di Kecamatan Bolangitang Timur Kabupaten Bolaang Mongondow Utara. Zootek. 36:191-197. doi:10.35792/zot.36.1.2016.10469.

7. Amam, Z. Fanani, B. Hartono, and B. A. Nugroho. 2019. The power of resources in independent livestock farming business in Malang District, Indonesia. Anim. Sci. Food Tech. Conf. p. 1-9. doi:10.1088/1755-1315/372/1/012055.

8. Amam, M. W. Jadmiko, P. A. Harsita, and R. Yulianto. 2019. Internal resources of dairy cattle farming business and their effect on institutional performance and business development. Animal Production. 21:157-166. doi:10.20884/1.jap. 2019.21.3.738.

9. Amam, M. W. Jadmiko, P. A. Harsita, and M. S. Poerwoko. 2019. Model pengembangan usaha ternak sapi perah berdasarkan aksesibilitas sumber daya. Jurnal Sain Peteternakan Indonesia. 14:61-69. doi:10.31186/jspi.id.14.1.61-69.

10. Amam, M. W. Jadmiko, P. A. Harsita, N. Widodo, and M. S. Poerwoko. 2019.
Sumber daya internal peternak sapi perah dan pengaruhnya terhadap dinamika kelompok dan konteks kerentanan. Jurnal Ilmiah Peternakan Terpadu. 7:192-200. doi:10.23960/jipt.v7i1.p192-200.

11. Amam. and Soetriono. 2020. Peranan sumber daya terhadap SDM peternak dan pengembangan usaha ternak sapi perah di kawasan peternakan sapi perah nasional (KPSPN). Jurnal Peternakan Indonesia. 22:1-10. doi:10.25077/jpi.22.1.1-10.2020.

12. Soetriono, D. Soejono, D. B. Zahrosa, A. D. Maharani, and Amam. 2019. Strategi pengembangan dan diversifikasi sapi potong di Jawa Timur. Jurnal Ilmu dan Teknologi Peternakan Tropis. 6:138-145. doi:10.33772/jitro.v6i2.5571.

13. Amam, Z. Fanani, B. Hartono, and B. A. Nugroho. 2019. Identification of resources in the system of broiler farming business. Jurnal Ilmu Ternak dan Veteriner. 24:135-142. doi:10.14334/jitv.v24.3.1927.

14. Riszqina, Isbandi, E. Rianto, and S. I. Santoso. 2014. The analysis of factor affecting the performance in benefits of karapan (racing) cattle business in Madura Island, East Java. J. Indonesian Trop. Anim. Agric. 39:65-72. doi:10.14710/jitaa.39.1.65-72.

15. Asmara, A., Y. L. Purnamadewi, and D. Lubis. 2017. The relationship analysis between service performances of milk producer cooperative with the dairy farm performance of membes. Media Peternakan. 40:143-150. doi:10.5398/medpet.2017.40.2.143.

16. Amam. and N. Solikin. 2020. The effect of resources on institutional performance and vulnerability aspects of dairy cattle business. Proc. Int. Conf. Eco. Bus. Gov. Challenges. p. 1-9. doi:10.4108/eai.3-102019.2291919.

17. Muhajirin, Despal, and Khalil. 2017. Pemenuhan kebutuhan nutrient sapi potong bibit yang digembalakan di Padang Mengatas. Buletin Makanan Ternak. 104:9-20.

18. Suresti, A. and R. Wati. 2012. Strategi pengembangan usaha peternakan sapi potong di Kabupaten Pesisir Selatan. Jurnal Peternakan Indonesia. 14:249-262. doi:10.25077/jpi.14.1.249-262.2012. 
19. Amam. and P. A. Harsita. 2019. Pengembangan usaha ternak sapi perah: Evaluasi konteks kerentanan dan dinamika kelompok. Jurnal Ilmiah Ilmu-Ilmu Peternakan. 22:23-34. doi:10.22437/jiiip.v22i1.7831.

20. Gayatri, S. and M. Vaarst. 2015. The implementation of Indonesia's Beef Self-Sufficiency Programme (BSSP) as seen from a farmer-family perspective. JRCD. 10:166-186.

21. Amam. and P. A. Harsita. 2019. Tiga pilar usaha ternak: breeding, feeding, and management. Jurnal Sain Peternakan Indonesia. 14:431-439. doi:10.31186/jspi.id. 14.4.431-439.

22. Aiba, A., J. C. Loing, B. Rorimpandey, and L. S. Kalangi. 2018. Analisis pendapatan usaha peternak sapi potong di Kecamatan Weda Selatan Kabupaten Halmahera Tengah. Zootek. 38:149-159. doi:10.35792/ zot.38.1.2018.18622.

23. Amam, Z. Fanani, B. Hartono, and B. A. Nugroho. 2019. Pengembangan usaha ternak ayam pedaging sistem kemitraan bagi hasil berdasarkan aksesibilitas peternak terhadap sumber daya. Jurnal Ilmu Teknologi Peternakan Tropis. 6:146-153. doi:10.33772/jitro.v6i2.5578.

24. Amam, Z. Fanani, B. Hartono, and B. A. Nugroho. 2019. Usaha ternak ayam pedaging sistem kemitraan pola dagang umum: Pemetaan sumber daya dan model pengembangan. Si. Pet. 17:5-11. doi:10.20961/sainspet.v17i2.26892.

25. Sunarto, E., O. H. Nono, U. R. Lole, and Y. L. Henuk. 2016. Kondisi ekonomi rumah tangga peternak penggemukan sapi potong pada peternakan rakyat di Kabupaten Kupang. Jurnal Peternakan Indonesia. 18:21-28. doi:10.25077/jpi.18.1.21-28.2016.

26. Hastang. and A. Asnawi. 2014. Analisis keuntungan peternak sapi potong berbasis peternakan rakyat di Kabupaten Bone. Jurnal Ilmu-Ilmu Peternakan. 1:240-252. doi:10.24252/jiip.v1i3.1548.

27. Nurlaha., A. Setiana, and N. S. Asminaya. 2014. Identifikasi jenis hijauan makanan ternak di lahan persawahan Desa Babakan Kecamatan Dramaga Kabupaten Bogor.
Jurnal Ilmu dan Teknologi Ternak Tropis. 1:54-62. doi:10.33772/jitro.v1i1.361.

28. Ashari, Saptana, and T. B. Purwantini. 2012. Potensi dan prospek pemanfataan lahan pekarangan untuk mendukung ketahanan pangan. Forum Penelitian Agroekonomi. 30:13-30. doi:10.21082/fae.v30n1.2012.13-30.

29. Amam, Z. Fanani, B. Hartono, and B. A. Nugroho. 2019. Identifikasi sumber daya finansial, teknologi, fisik, ekonomi, lingkungan, dan sosial pada usaha ternak ayam pedaging. Pros. Sem. Nas. Tek. Pet. Vet. p. 738-746. doi:10.14334/Pros.Semnas.TPV-2019-p.738 -746 .

30. Amam. and P. A. Harsita. 2019. Efek domino performa kelembagaan, aspek risiko, dan pengembangan usaha terhadap SDM peternak sapi perah. Si. Pet. 17:5-11. doi:10.20961/sainspet.v\%vi\%i.24266. 